\title{
Kompromi Islam dan Adat pada Praktik Keagamaan Muslim Bugis di Sulawesi Selatan
}

\author{
Hasse Jubba, ${ }^{1}$ Ahmad Sultra Rustan, ${ }^{2}$ Juhansar ${ }^{3}$ \\ ${ }^{1}$ Program Doktor Politik Islam - Ilmu Politik Universitas Muhammadiyah Yogyakarta \\ ${ }^{2}$ Institut Agama Islam Negeri Parepare, ${ }^{3}$ Universitas Teknologi Yogyakarta \\ (e-mail: ${ }^{1}$ hasse@umy.ac.id; ${ }^{2}$ ahmadsultrarustan@stainparepare.ac.id; \\ 3juhansarandilatief@gmail.com)
}

\begin{abstract}
This article explores the form of compromise between Islam and local tradition (adat) in the religious practices of Muslims in Bugis community in South Sulawesi. Islam is an integral part of Bugis lives and is positioned as the main reference so that it encourages Bugis community members to become more fanatic than others. However, in some cases, it is not uncommon for religious practices that have traditional nuances. In fact, the local tradition is in a position that exceeds the role of religion as reflected in the celebration of Islamic holidays. This condition allows the attraction between religion and local tradition to occur in the practice of everyday life of the Bugis community. The question is at what level do conflicts and compromises occur between local tradition and religion among the Bugis community? To answer this question, an investigation was carried out using qualitative methods that put forward and applying the techniques of participant observation and literature study. The results show that points of compromise were discovered where religion and local tradition complemented each other. The tendency to compromise Islam and local tradition is motivated by not only the low understanding of religion itself but also the desire to maintain the ancestral local traditions that have been practiced for a long time in their community. The compromise of Islam and local tradition in religious practices have resulted in the escape of their respective positions, and it makes the role of religion tends to weaken.
\end{abstract}

Artikel ini mengeksplorasi bentuk kompromi antara Islam dan adat dalam praktik beragama Muslim Bugis di Sulawesi Selatan. Islam merupakan bagian integral dari kehidupan mereka dan diposisikan sebagai referensi utama sehingga praktik beragamanya sangat fanatik. Namun demikian, pada beberapa hal tidak jarang terdapat praktik beragama yang bernuansa adat. Bahkan, adat berada pada posisi melebihi peran agama seperti yang tercermin pada perayaan hari-hari besar Islam. Kondisi ini memungkinkan terjadi tarik menarik antara agama dan adat dalam praktik kehidupan masyarakat Muslim Bugis sehari-hari. Pertanyaan, pada level apa konflik dan kompromi terjadi antara adat dan agama di kalangan orang Bugis? Untuk menjawab pertanyaan ini, dilakukan sebuah penyelidikan dengan menggunakan metode kualitatif yang mengedepankan teknik observasi partisipan dan studi kepustakaan. Hasilnya menunjukkan bahwa ditemukan titik-titik kompromi dimana antara agama dan adat saling melengkapi. Kecenderungan mengkompromikan Islam dan adat dilatarbelakangi oleh bukan hanya pemahaman agama yang masih rendah, tetapi juga keinginan untuk tetap mempertahankan adat warisan leluhur yang telah dipraktikkan sejak lama. Kompromi Islam dan adat dalam praktik beragama berdampak pada kaburnya posisi masing-masing, bahkan peran agama cenderung melemah.

Keywords: compromise; Islam; local tradition; fanatism; Buginese Muslim 


\section{Pendahuluan}

Upaya mengkompromikan Islam dan adat dalam praktik beragama sangat lazim ditemukan di kalangan Muslim Indonesia. Kondisi ini memberikan penjelasan atas belum tuntasnya persoalan pemahaman dan pengamalan ajaran Islam di kalangan umat. Pemahanan terhadap Islam memang selalu memiliki sisi yang cenderung melemah, seiring dengan melemahnya pranata keislaman akibat gempuran kekuatan besar dari luar yang secara langsung berdampak pada keinginan untuk belajar lebih dalam mengenai ajaran Islam. Tingkat pemahaman yang rendah atas ajaran Islam dapat dilihat pengaruhnya pada praktik beragama yang selama ini berlangsung di kalangan Muslim. Pada kalangan Muslim Bugis missalnya, pada berbagai perisitiwa kondisi ini dapat dilihat dengan jelas. Bahkan, sulit lagi mengatakan bahwa apakah praktik tersebut merupakan praktik agama (Islam) atau justru merupakan bagian dari adat atau tradisi di luar Islam.

Islam dan adat telah menjadi bagian integral dari kehidupan orang Bugis (Hasse 2018; Pelras 2006). Di tengah sikap fanatik orang Bugis dalam menjalankan Islam, keteguhan mereka mempertahankan adat istiadat juga dapat ditemukan. Ada dua kutub yang sering bertentangan. Sebab, mereka selain dikenal sebagai penganut Islam fanatik, juga dikenal sangat loyal terhadap adat. Pada praktik kehidupan, antara adat dan Islam tidak hanya diperlawankan, tetapi juga dikompromikan. Memang, adat merupakan warisan nenek moyang yang diakui masih memiliki fungsi yang luhur sehingga masih dipertahan- kan karena merupakan pedoman untuk mendapatkan kebahagiaan dunia (Abdullah 1999). Demikian pula agama, ia dianggap sebagai sebuah media untuk memenuhi kebutuhan batin dan pegangan yang memiliki nilai agung yang dapat menuntun penganutnya ke arah yang benar (Durkheim 1995; Geertz 1973).

Praktik Islam di kalangan Muslim Bugis secara perlahan membentuk sebuah sikap fanatik dalam beragama. Fanatisme ini pun dapat disamakan dengan fanatisme orang Aceh, Banjar, Betawi, dan Banten dalam mengamalkan Islam dalam kehidupannya. Ketaatan mereka dapat dilihat melalui praktik-praktik yang dilakukan seperti pelaksanaan ibadah dan perayaan-perayaan hari besar Islam yang disambut dengan antusias yang tinggi. Ibadah puasa dan haji misalnya, orang Bugis melaksanakannya dengan penuh kemeriahan. Bahkan, ibadah haji yang semestinya bernuansa ibadah, di kalangan Muslim Bugis ditampilkan dalam nuansa adat yang lebih kental karena diselingi dengan praktik yang jauh di luar tuntunan agama. Misalnya, bagi yang telah menunaikan ibadah haji dalam kehidupan sosial memiliki 'tempat' (baca: status) yang berada di atas kalangan umum lainnya. Bahkan, kedatangan orang yang telah menunaikan ibadah haji tidak ubahnya kedatangan tamu agung dan harus dipestakan. Hal ini dapat dilihat pada dua sisi yang saling bertolak belakang sekaligus saling mendukung. Sebab, perilaku tersebut diwujudkan dalam rangka menghargai tamu Allah yang baru saja menunaikan ibadah di satu pihak. Sementara itu, kecenderungan tersebut justru 
keluar dari substansi ibadah yang salah satunya menjadikan seseorang lebih rendah hati, tidak boros, dan sebagainya. Pada praktik ini dapat dilihat bahwa adat diperlakukan seperti halnya agama yang melebur dalam satu peristiwa.

Tulisan ini mengeksplorasi lebih dalam mengenai bentuk kompromi yang terjadi antara adat dan agama pada praktik beragama Muslim Bugis. Pada level apa konflik dan kompromi terjadi antara adat dan agama di kalangan orang Bugis? Untuk menjawab pertanyaan ini, kajian dalam artikel ini didasarkan pada hasil penelitian yang dilakukan denangan metode kualitatif yang proses penggalian datanya mengedepankan cara-cara observasi langsung penulis atas kehidupan masyarakat Muslim Bugis di Sulawesi Selatan dan kajian kepustakaan. Namun, perlu disampaikan di sini bahwa sebagian dari isi artikel ini pernah diterbitkan dalam bentuk buku (kumpulan tulisan), tetapi terbitan ini telah dilakukan beberapa revisi dan penambahan baik dari aspek substansi maupun teknis, temasuk pembaruan literatur.

Untuk membantu pemahaman pembaca, dalam artikel ini sebelum memeberikan narasi yang menjawab pertanyaan di atas artikel ini diawali dengan memberikan gambaran umum tentang identitas orang Bugis dan proses pengenalan Islam serta dinamika keberislaman di antara mereka. Selanjutnya, artikel ini juga akan mengupas isu islamisasi pada awal masuknya Islam di tanah Bugis yang menunjukkan adanya pro dan kontra di kalangan orang Bugis.

\section{Identitas Orang Bugis}

Bugis adalah salah satu suku bangsa yang mendiami wilayah bagian Selatan Pulau Sulawesi yang saat ini dikenal dengan Sulawesi Selatan. Orang Bugis merupakan etnis terbesar dengan persentase $41.90 \%$ dari jumlah penduduk Sulawesi Selatan (Suryadinata, dkk. 2003: 65). Di Sulawesi Selatan sendiri, selain orang Bugis juga terdapat orang Makassar, Toraja, dan Mandar. Mandar saat ini berada di Sulawesi Barat setelah pemekaran wilayah. Wilayah yang didiami oleh orang Bugis meliputi Kabupaten/Kota Bone, Soppeng, Wajo, Sidenreng Rappang, Pinrang, Luwu, Parepare, Barru, dan Sinjai. Sementara kabupaten seperti Maros, Pangkajene Kepulauan, Bantaeng, dan Bulukumba didiami oleh orang Bugis dan sebagian Makassar. Adapun daerah seperti Tana Toraja, orang Bugis merupakan etnis minoritas.

Terdapat dua pendapat utama mengenai asal-usul orang Bugis (To Ugi). Pertama, orang Bugis berasal dari India Belakang seperti halnya suku bangsa lain di Nusantara. Menurut pendukung pendapat, orang India Belakang datang secara bergelombang ke Nusantara pada ribuan tahun lalu. Orang Bugis, menurut pendapat ini, digolongkan dalam rumpun atau turunan Melayu Muda (Deutero Melayu) yang datang ke wilayah Sulawesi Selatan. Sebelum mereka datang, Melayu Tua (Proto Melayu) terlebih dahulu memasuki wilayah ini (Hamzah 1984: 34-35). Pendapat ini juga didukung oleh fakta bahwa saat ini orang Bugis banyak yang telah beranak-pinak di beberapa daerah Melayu seperti Sumatera dan Kalimantan, bahkan di Malaysia. Pendapat pertama ini juga 
mendukung asumsi bahwa Islam masuk ke Indonesia berasal dari India.

Kedua, orang Bugis merupakan salah satu rumpun dari orang Austronesia yang tersebar di beberapa tempat di Asia Tenggara (Pelras 2006). Penyebaran rumpun ini dalam perkembangannya melahirkan suku bangsa seperti Melayu, Bali, dan Jawa. Namun, mereka lebih terkenal dibandingkan Bugis. Pada abad ke-19, penyebaran orang Bugis telah merambah Singapura hingga Papua, dari bagian Selatan Filipina hingga ke pantai Barat Australia. Adapula yang mengatakan bahwa orang Bugis pernah menyeberangi samudera Hindia sampai ke Madagaskar sehingga keturunannya masih dapat dilacak di daerahdaerah tersebut. Dari keterangan ini, orang pun mengatakan bahwa orang Bugis merupakan pelaut ulung di masanya karena kemampuan mengarungi lautan dengan keterbatasan alat pelayaran yang dimiliki. Pendapat ini merupakan pendapat yang banyak dijadikan rujukan mengenai asal-usul orang Bugis.

Kedua pendapat di atas setidaknya memberikan gambaran mengenai asal-usul orang Bugis meskipun terdapat perbedaan persepsi. Tidak hanya pada persoalan asal-usul, batasan mengenai siapakah yang termasuk orang Bugis pun sulit ditetapkan. Untuk memberikan batasan terhadap orang Bugis, penulis meminjam kerangka yang digunakan oleh Muhammad Damami (2002) untuk memberikan gambaran mengenai definisi masyarakat Jawa. Menurutnya, masyarakat Jawa adalah masyarakat yang beretnis Jawa yang masih memiliki komitmen terhadap kebudayaan
Jawa, apakah mereka tinggal di Jawa atau pun di luar Jawa. Mengacu pada pendapat ini, dapat dikatakan bahwa orang Bugis adalah orang yang memiliki ikatan dengan kebudayaan Bugis, baik yang tinggal di Sulawesi Selatan maupun yang tinggal di luar daerah tersebut. Definisi ini mencakup bahasa dan geneologi atau silsilah keluarga orang Bugis.

Penyebaran orang Bugis yang mampu menjangkau ke berbagai wilayah di luar Sulawesi Selatan, menjadikan mereka sering diidentikkan dengan pelaut ulung. Informasi seperti ini merupakan informasi yang keliru. Alasan ini didasarkan pada fakta bahwa aktivitas maritim orang Bugis baru benar-benar berkembang pada abad ke-18. Adapun perahu pinisi, yang sering dilekatkan dengan kepelautan orang Bugis, baru ditemukan antara penghujung abad ke-19 hingga dekade 1930-an (Pelras 2006: 4). Demikian pula, predikat bajak laut yang diberikan kepada orang Bugis merupakan sesuatu yang keliru. Justru, orang Bugis merupakan petani yang ulet. Aktivitas maritim hanya digandrungi oleh mereka yang tinggal di sekitar pantai yang jumlahnya lebih sedikit jika dibandingkan dengan orang Bugis yang berdomisili di sekitar daerah daratan/ pegunungan. Mayoritas orang Bugis justru berada jauh dari laut yang mayoritas berprofesi sebagai petani sawah. Kebiasaan orang Bugis merantau dan menetap di negeri lain kemungkinan menjadi pemicu utama persepsi sebagai pelaut terhadap mereka.

Bagi suku-suku bangsa yang tinggal di sekitar komunitas orang Bugis, mengenal mereka sebagai orang yang berkarakter keras dan menjunjung tinggi kehormatan. Bahkan demi 
kehormatan (siri'), orang Bugis rela melakukan tindak kekerasan. Sebab, siri' merupakan harga diri yang mesti dipertahankan. Karakter keras menjadi label orang Bugis karena keteguhan mempertahankan sesuatu dan keberanian menghadapi tantangan (Rustan 2018). Terlepas dari stigma karakter keras, mereka juga dikenal dengan penghargaan yang tinggi terhadap orang lain dan memiliki kesetiakawanan yang kuat. Di berbagai wilayah di Nusantara, orang Bugis dapat ditemukan dengan berbagai bentuk aktivitas. Mereka sibuk dengan aktivitas pelayaran, perdagangan, pertanian, dan berbagai pekerjaan yang lain.

\section{Adat dan Islam: Suatu Konseptual Singkat}

Adat merupakan sesuatu yang dilakukan secara berulang dan cenderung dipertahankan dalam sebuah kelompok/komunitas. Adat pada komunitas tertentu memiliki posisi penting, bahkan mengalahkan posisi agama pada persoalan-persoalan yang bersifat ritual. Adat adalah aturan-aturan tentang kehidupan manusia yang disepakati penduduk dalam suatu daerah tertentu untuk mengatur tingkah laku anggotanya sebagai kelompok social (Said 2004: 25). Dalam Islam, istilah adat sering diparalelkan dengan 'urf yang juga berarti adat atau kebiasaan. Kebiasaan artinya sesuatu yang dilakukan secara berulang dan biasanya memiliki pola tertentu tergantung kesepakatan dalam sebuah komunitas/kelompok. Adat suatu daerah dengan daerah lain ada yang sama dan ada pula yang berbeda. Perayaan Maulid Nabi misalnya, pada komunitas tertentu dilakukan secara besar-besaran seperti yang ditunjukkan oleh pengikut Tarekat Khalwatiah di Sulawesi Selatan. Setiap tahun, mereka merayakan Maulid Nabi di Maros, Sulawesi Selatan. Menurut mereka, maulid (tidak afdhal/sah) jika hanya dirayakan di kampungkampung sendiri, tanpa melaksanakan di tempat ini (data: observasi pribadi penulis).

Terminologi Islam dapat dipahami setidaknya terkait dengan dua hal pokok, sebagai identitas dan sebagai ajaran. Sebagai identitas, Islam merupakan nama sebuah agama yang diturunkan kepada Nabi Muhammad melalui perantara malaikat Allah. Islam sebagai ajaran atau agama diturunkan berfungsi sebagai pedoman agar manusia dapat menentukan mana yang baik dan mana yang buruk serta yang hak dan yang batil (Karim 2007: 27). Ajaran-ajaran Islam termaktub secara jelas dan tegas dalam sebuah kitab, yaitu al-Qur'an. Dalam kitab inilah seluruh ajaran Islam dapat ditemukan. Secara kebahasaan, istilah Islam berasal dari kata aslama, yuslimu, islaam. Kata ini memiliki banyak makna, salah satunya ketundukan (baik lahir maupun batin). Artinya, Islam mengandung makna sikap yang berhubungan dengan ketundukan, kepatuhan, dan penyerahan diri sepenuhnya kepada hukum Allah (Kambie 2003: 70).

Dalam kehidupan masyarakat Bugis di Sulawesi Selatan, baik Islam maupun adat seringkali hadir dalam satu aktivitas secara bersamaan. Perayaan hari-hari besar Islam misalnya, kedua entitas ini sering hadir bersamaan dan sulit lagi dipisahkan. Kebiasaan seperti ini tidak hanya terjadi pada masyarakat Bugis, tetapi juga pada masyarakat Muslim di berbagai tempat pemandangan serupa dapat 
di temukan. Di Gorontalo misalnya, masyarakat Muslim dalam merayakan Isra' mi'raj, memadukan Islam dan adat pada kegiatan tersebut. Ini ditunjukkan sangat kuat pada perayaan Isra' Mi'raj yang dilakukan oleh masyarakat Muslim dengan diselingi membaca naskah-naskah klasik local (Tohopi 2012). Bagi penulis, ini merupakan bagian dari dinamika keberislaman masyarakat Muslim khususnya di Indonesia yang tidak bisa dilepaskan begitu saja dari konteks tradisi sebelum Islam. Meskipun Islam telah menjadi agama resmi dan menjadi rujukan utama masyarakat Muslim, namun tetap saja terdapat ruang praktik yang mengakomodasi dan mengkompromikan Islam dengan adat.

\section{Proses Pengenalan Islam}

Sejak abad ke-17, orang Bugis telah mengenal Islam. Namun, secara formal, Islam di Sulawesi Selatan diperkenalkan oleh tiga datuk dari Koto Tangah, Minangkabau pada permulaan abad ke-17 (Sewang 2005: 89). Ketiga datuk tersebut yang dikenal dengan datuk tellue (Bugis) atau datuk tallua (Makassar) adalah Abdul Makmur, Khatib Tunggal, yang dikenal dengan Datuk ri Bandang memiliki keahlian pada bidang fikih; Sulaiman, Khatib Sulung, dikenal dengan Datuk Patimang, seorang ahli tauhid; dan Abdul Jawad, Khatib Bungsu, dikenal dengan Datuk ri Tiro, seorang ahli tasawuf. Menurut sejarah, Islam pertama kali dikenal di Kerajaan Luwu sekitar tahun 1589 kemudian Gowa-Tallo pada tahun 1603. Penerimaan Islam di kerajaan tersebut diikuti oleh beberapa kerajaan lain seperti Kerajaan Sidenreng pada tahun 1605, Soppeng pada tahun 1607, Wajo pada tahun 1609, dan Bone pada tahun 1611 (Arsyad 2000). Penerimaan Islam pada beberapa kerajaan terakhir berlangsung setelah jalan perang dilancarkan oleh Kerajaan Gowa-Tallo.

Kedatangan ketiga datuk di Makassar merupakan upaya yang dilakukan oleh pedagang Melayu (Muslim) yang tidak senang melihat orang Bugis-Makassar terpengaruh oleh ajaran Kristen (Katolik). Persaingan untuk mendapatkan simpati dari orang Bugis-Makassar antara misionaris Katolik dan pedagang Melayu telah lama berlangsung. Hal ini dikemukakan oleh seorang misionaris, Antonio de Payva, yang berkunjung ke Makassar pada tahun 1542. Kedatangan ketiga datuk ke Makassar ketika itu merupakan utusan dari Kerajaan Aceh (Sewang 2005: 90). Mereka diutus atas permintaan Karaeng Matoaya, Raja Tallo. Ketiga datuk inilah yang menyebarkan Islam di tanah Bugis-Makassar. Ajaran Islam yang dibawa merupakan ajaran seperti yang dianut oleh masyarakat di daratan Sumatera yang sangat fanatik yang kalah itu berada di bawah kekuasaan Kerajaan Aceh.

Secara umum, ada dua cara penyebaran Islam di Sulawesi Selatan khususnya di tanah Bugis. Pertama, Islam disebarkan melalui cara damai. Cara ini dilakukan dengan sistem topdown, melalui media penguasa seperti yang telah disinggung di atas. Penerimaan Islam oleh penguasa (raja) akan dengan mudah diikuti oleh rakyatnya. Cara ini merupakan cara yang dilakukan oleh ketiga datuk dalam menyebarkan Islam (Sewang 2005). Hal ini dilakukan karena mereka melihat kuatnya pa- 
tron antara masyarakat dan pemimpinnya. Cara ini ternyata berhasil dilakukan dan penyebaran Islam berlangsung dengan cepat. Penerimaan penguasa terhadap Islam direspons oleh masyarakat. Di beberapa kerajaan, Islam diterima dengan baik, namun di beberapa kerajaan lain terjadi penolakan. Penolakan kerajaan terhadap Islam direspons oleh kerajaan kembar, Gowa-Tallo, dengan perang sebagai wujud komitmennya terhadap penyebaran Islam.

Kedua, Islam disebarkan melalui 'perang'. Cara ini dikenal dengan sistem bottom-up. Beberapa kerajaan menerima Islam setelah mendapat tekanan dari Kerajaan Gowa-Tallo. Kerajaan Bone, Soppeng, dan Wajo merupakan kerajaan yang menerima Islam sebagai agama kerajaan setelah ditaklukkan (Sewang 2005: 117). Penaklukan ketiga kerajaan tersebut berdampak pada kelancaran penyebaran Islam di tanah Bugis. Ketiga kerajaan ini menjadi barometer kerajaan- kerajaan kecil yang lain untuk menerima Islam karena ketiganya masing-masing membawahi kerajaankerajaan kecil di sekitarnya. Penekanan muballigh di daerah ini adalah pengikisan paham-paham lama yang bercorak animisme dan dinamisme seperti halnya yang masih terjadi pada komunitas Muslim di berbagai tempat di Indonesia.

\section{Islamisasi: Upaya Mereduksi Adat}

Penolakan sebagian masyarakat seperti masyarakat Wajo terhadap Islam memperlihatkan bahwa Islam disampaikan tidak berjalan lancar. Meskipun penguasa menjadikan
Islam sebagai agama resmi kerajaan, namun tidak serta-merta diterima oleh seluruh masyarakat. Keputusan politik penguasa Wajo yang ditolak oleh sebagian masyarakatnya dengan bermigrasi (Kesuma 2004). Migrasi orang Towani dari Wajo ke Sidenreng pada abad ke-17 merupakan bentuk penolakan mereka terhadap Islam. Migrasi ini mencerminkan kuatnya keyakinan terhadap ajaran yang dianut. Ajaran warisan leluhur sangat dipegang teguh dan dipraktikkan. Towani masih mempertahankan keyakinan tersebut hingga saat ini di Sidenreng Rappang (Hasse 2018).

Islam disampaikan tidak secara prontal yang mengubah kebiasaan orang Bugis secara bertahap. Salah satu kesulitan yang dihadapi oleh datuk adalah mengubah kebiasaan dan kegemaran orang Bugis seperti bermain judi, mabuk-mabukan, dan memakan babi. Sebab, kebiasaan bermain judi tidak hanya dilakukan oleh masyarakat biasa, tetapi juga oleh penguasa. Obsevasi pribadi penulis menemukan bahwa bermain judi seperti sabung ayam sangat diminati sebagian masyarakat karena di dalamnya juga terdapat unsur hiburan. Kebiasaan seperti ini juga dipraktikkan oleh masyarakat Bali (Geertz 1973). Sabung ayam terlepas dari unsur permainan judi, juga dipahami sebagai sarana hiburan. Kebiasaan sabung ayam bukan hanya dianggap permainan judi karena di dalamnya terjadi peredaran uang yang cukup signifikan, tetapi juga dianggap sebagai sarana pemersatu dan penyampai informasi. Pandangan ini didasarkan pada kondisi dimana dalam praktik sambung ayam 
juga memungkin seseorang untuk mendapatkan berbagai informasi yang tersebar di dalam proses itu. Bahkan, tidak jarang pertemuan antara orang per orang dan kelompok justru terjadi di tempat ini. Berbagai diskusi pun berlangsung di tengah perhelatan sabung ayam tersebut.

Selain itu, penerimaan masyarakat dan penguasa Bugis terhadap Islam tidak lepas dari kepiawaian para datuk menyampaikan dakwahnya. Keahlian mereka mampu membantah dan mengubah keyakinan mayoritas orang Bugis yang kuat menganut animisme dan dinamisme (Nasruddin 2017). Animisme dan dinamisme merupakan ajaran dominan yang dianut oleh orang Bugis pra-Islam. Kedua paham tersebut hadir dan menjadi bagian yang tidak dapat dipisahkan dari kehidupan orang Bugis. Namun, keahlian para datuk mampu mengubah keyakinan tersebut. Keahlian dalam bidang fikih (hukum Islam), tauhid (teologi), dan tasawuf (tarekat) oleh ketiga datuk memudahkan pemetaan wilayah penyebaran Islam. Di sini tampak bahwa penyebaran Islam didasarkan pada perhitungan yang cermat oleh pada datuk. Penyebaran Islam di Sulawesi Selatan memiliki pola yang hampir sama dengan apa yang dilakukan oleh para wali di Jawa. Hanya saja, sasaran penyebaran Islam di daerah Sulawesi Selatan bersifat top-down, dari penguasa kemudian ke rakyatnya.

Seperti yang telah dikemukakan sebelumnya, ketiga datuk yang datang memperkenalkan Islam di tanah Bugis dan sekitarnya memiliki keahlian yang berbeda. Penyampaian Islam pun didasarkan pada keahlian dan persoalan lapangan yang dihadapi. Islam yang diperkenalkan pada masing-masing daerah berbeda dengan daerah lain dari segi metode. Di wilayah yang masyarakatnya termasuk penganut ajaran leluhur yang kuat menjadi bagian datuk yang ahli dalam tauhid, demikian seterusnya. Dengan demikian, melihat penyebaran Islam di tanah Bugis khususnya, dan di Sulawesi Selatan umumnya, yang dilakukan oleh ketiga datuk terdiri atas tiga pola, yaitu pola syariat, tauhid, dan tasawuf. Satu hal yang tidak dapat diabaikan mengenai penyebaran Islam di tanah Bugis adalah keterlibatan pedagang Melayu, yang telah lama melakukan aktivitas perdagangan dan kontak sosial dengan orang Bugis, dalam hal pemberian informasi kepada datuk.

Keberhasilan penyebaran Islam di Bugis merupakan keberhasilan dakwah yang luar biasa. Islam telah menjadi agama dianut secara baik/taat oleh masyarakat Bugis di sebagian besar wilayah Sulawesi Selatan. Bentuk ketaatan mereka ditunjukkan dengan antusiasme membangun sarana ibadah. Di berbagai penjuru seperti di setiap kabupaten/kota berdiri bangunan masjid yang megah. Ketaatan mereka terhadap Islam juga dapat dilihat dari ibadah dan perayaan yang dilakukan. Setiap waktu shalat terdengar suara adzan di masjid-masjid. Pada bulan Ramadhan, masjidmasjid dipenuhi oleh umat Islam untuk melakukan ibadah tahunan ini. Setiap perayaan hari besar Islam juga demikian. Mereka memenuhi masjid dan mengikuti ceramah agama dengan hikmat, perayaannya pun dilakukan dengan meriah. Dari segi kuantitas penganut, mayoritas orang Bugis adalah penganut Islam. 


\section{Ambivalensi Prilaku dalam Beragama}

Islam dan adat tidak bisa dipisahkan dari kehidupan orang Bugis (Pelras, 2006:216). Keduanya telah terintegrasi dalam setiap perilaku sosial maupun keagamaan. Dalam upacara kematian misalnya, unsur adat dan Islam sulit dipisahkan. Seorang (Islam) yang meninggal, melalui prosesi kematian secara islami (dimandikan, dikafani, dishalatkan, dan dimakamkan). Namun, ketika jenazah hendak dimakamkan, ia dikeluarkan tidak melalui pintu. Menurut anggapan sebagian orang Bugis, pintu merupakan jalan bagi orang yang hidup, orang yang telah meninggal memiliki jalan sendiri. Jika pintu digunakan untuk jalan bagi si mati, maka ia akan terus memanggil penghuni rumah untuk mengikutinya. Demikian salah satu keyakinan yang terus dikonstruksi dan diwariskan ke generasi mereka. Praktik seperti ini biasanya dilakukan oleh Towani Tolotang dalam prosesi kematian warganya. Hal ini memperlihatkan kuatnya pengaruh tradisi pra-Islam di kalangan orang Bugis. Praktik beragama yang masih bercampur-aduk dengan adat dalam terma Clifford Geertz (1983) disebutnya sebagai Islam abangan (Hasse 2008).

Pemahaman terhadap ajaran Islam yang masih kurang menimbulkan berbagai bentuk praktik yang menyimpang. Kasus di atas setidaknya menegaskan asumsi ini. Islam dipahami hanya pada tataran pelaksanaan saja seperti shalat, zakat, haji, dan sebagainya tanpa mendalami lebih jauh. Hal ini terjadi disebabkan oleh pewarisan Islam yang dilakukan melalui keturunan. Di sini, Islam dianut hanya karena faktor kebetulan, bukan karena melalui proses penerimaan yang sempurna. Kiranya tidak heran jika di kalangan masyarakat masih terdapat bentuk-bentuk praktik Islam yang tidak dilakukan secara komprehensif atau kaffah. Dengan demikian, Islam hanya dipahami dan dilaksanakan berdasarkan apa yang telah dilakukan oleh lingkungan keluarga yang telah lebih jauh memeluk Islam.

Sikap mengkompromikan adat dan Islam dalam kehidupan keberagamaan orang Bugis sesungguhnya bukanlah hal baru. Sebab, sikap tersebut telah tercermin dalam konsep panngdereng (adat) dalam masyarakat Bugis. Panngadereng berarti sesuatu yang menjadi tempat berpijak perilaku dan kehidupan masyarakat Bugis dan Makassar. Dalam konsep panngadereng sendiri, terdapat lima nilai pokok yang menjadi nilai utama orang Bugis dalam menata kehidupan. Salah satu nilai selain adat adalah syara' atau agama yang merupakan bagian dari unsur panngadereng (Rustan 2018: 54). Kesulitan memisahkan Islam dari adat dapat dikatakan tersirat dalam konsep ini. Terdapat kecenderungan pengintegrasian adat ke dalam agama, dan sebaliknya. Proses atau adatisasi agama dan agamisasi adat terus berlangsung dengan format yang sering pula berulang. Dalam perayaan Islam seperti maulid, unsur adat pun dilibatkan. Di masjid atau di tempat lain dapat disaksikan sederetan batang pisang yang dihiasi telur. Telur disimbolkan dengan kebulatan tekad beragama. Telur juga disimbolkan sebagai sesuatu yang bernilai penyatuan. Demikian pula pada acara keislaman seperti akikah, pernikahan, dan syukuran. Hiasan telur seperti pada perayaan maulid juga dapat ditemukan. Upacara ini dalam istilah orang Bugis disebut 
mammauluk atau maulid. Aktivitas maulid bukan hanya dimaknai sebagai perayaan atas kelahiran Nabi, tetapi juga diperuntukkan sebagai rasa penghormatan atas Nabi dan dilakukan pada berbagai siklus kehidupan orang Bugis seperti akikah dan sebagainya. Praktik berislam seperti ini, mungkin, seperti dalam diskusi Al Makin (2016) yang menyatakan bahwa Islam itu memang tidak tunggal (satu) dalam aktualisasinya.

Bentuk kompromi antara dua entitas yang berbeda seperti yang diuraikan di atas masih berlangsung hingga saat ini. Perayaan maulid diiringi dengan tidakan-tindakan adat merupakan bentuk nyata kompromi tersebut. Saat ini, perayaan maulid baik di masjid-masjid maupun di tempat lain masih menghadirkan aneka macam hiasan telur yang ditancapkan di batang pisang. Mammauluk dalam pemahaman orang Bugis tidak jauh berbeda dengan pemahaman orang Islam secara umum. Namun, mammauluk sering dikacaukan oleh pelaksanaan yang justru bukan pada bulan maulid. Pemahaman sebagian orang Bugis, mammauluk harus dilakukan ketika mendapat sesuatu yang lebih seperti halnya hendak menunaikan ibadah haji dan lain-lain. Dalam setiap perayaan maulid, pembacaan Barzanji tidak pernah absen. Pembacaan Barzanji inilah yang juga sering dilakukan pada setiap perayaan syukuran (tasyakuran) di kalangan orang Bugis sehingga perayaan tersebut sering dikatakan sebagai peristiwa mammauluk.

Uraian di atas menegaskan bahwa kainginan beragama yang kuat dan keteguhan mempertahankan adat masih berlangsung di tengah masyarakat Muslim Bugis hingga saat ini. Keteguhan orang Bugis mempertahankan kebiasaan melakukan ritual keagamaan yang dipadukan dengan adat memperlihatkan adanya posisi kuat adat dan Islam dalam praktik keagamaannya. Adat dan Islam masing-masing memiliki arena tersendiri dalam dinamika kehidupan orang Bugis sehingga antara keduanya tidak lagi memiliki batasan yang jelas (Abdullah 1999). Di sini terlihat telah terjadi pengaburan definisi yang sistematis antara adat dan Islam yang berdampak pada perilaku orang Bugis yang sarat dengan sinkretisme. Sebab, Islam datang atau masuk ke Indonesia bukan semata membangun peradaban, tetapi merebut peradaban (Geertz dalam Sumbulah 2012: 53) artinya terjadi perebutan ruang bahkan kuasa antara Islam dan tradisi lokal dan dampaknya masih terasa hingga saat ini.

\section{Kesimpulan}

Dari pemaparan panjang di atas, secara umum dapat ditarik kesimpulan umum dalam narasi berikut. Dimana pertarungan adat dan Islam di kalangan orang Bugis memberikan corak dalam mengamalkan Islam. Meskipun Islam diyakini sebagai agama yang berisi tentang ajaran-ajaran agung, namun tidak menjamin perilaku mereka terlepas dari adat. Posisi kuat adat yang telah mengakar dalam kehidupan orang Bugis menjadikannya sulit diabaikan. Di samping adat telah mengakar, pengabaiannya pun mendapatkan sanksi berupa sanksi sosial. Islam yang hingga saat ini terus didakwahkan belum mampu mengikis habis perilaku lama orang Bugis yang sangat 
fanatik terhadap adat. Pertemuan kedua elemen tersebut melahirkan fanatisme yang berlebihan sehingga tidak hanya menimbulkan konflik tetapi berbagai kompromi yang tercermin dalam praktik beragama dalam kehidupan. Pertemuan adat dan agama menciptakan ruang beragama baru bagi orang Bugis. Di satu sisi meraka mendapat kesempatan menunjukkan keteguhan mempertahakan kebiasaan lama, di sisi lain mereka dituntut untuk merespons Islam yang datang belakangan yang disertai ajaran dan tradisi yang serba baru.

Tulisan ini menegaskan beberapa kecenderungan. Pertama, orang Bugis sangat fanatik terhadap Islam. Tidak jarang ditemukan di kalangan masyarakat keengganan seseorang disebut non-Islam (non-Muslim) meskipun tidak melakukan kewajiban sebagai penganut Islam yang kaffah. Praktik keagamaan pun lebih banyak bersifat seremonial dan cenderung meninggalkan esensi ibadah pokok itu sendiri. Pada perayaan-perayaan hari-hari besar Islam tertentu, justru pelaksanaan atau proses pelaksanaan menjadi titik tekan, sementara makna perayaan justru kabur. Nuansa seremonial yang kental dan pengaruh adat sangat kuat sehingga cenderung menghilangkan substansi Islam. Ketersediaan instrumen atau perlengkapan acara lebih dikedepankan, sementara aspek ajaran ditinggalkan.

Kedua, kecenderungan teguh mempertahankan adat. Orang Bugis sangat loyal terhadap adat yang diwarisi dari para leluhur. Penghargaan terhadap adat dapat dilihat pada praktik Islam yang sering dicampuradukkan dengan praktik adat. Antara adat dan Islam sangat sulit dipisahkan dalam praktik keberagamaan yang dilakukan. Hal ini menunjukkan dualisme keyakinan yang sangat kental di kalangan orang Bugis masih terus terjadi hingga saat ini. Hal ini dikuatkan oleh masih adanya beberapa komunitas penganut ajaran (keyakinan) tertentu yang berbasis ajaran warisan leluhur yang merupakan orang Bugis.

Ketiga, kebiasaan-kebiasaan orang Bugis yang dilakukan masa pra-Islam masih membekas hingga saat ini. Dakwah Islam yang telah berlangsung lama hanya menyentuh sisi tertentu dan belum tuntas. Ceramah dan pengajian agama dilakukan oleh tokoh Islam tidak menjadi jaminan terhadap bersihnya perilaku mereka dari perbuatan yang menyimpang. Keteguhan mempertahankan adat, keengganan meninggalkan kebiasaan buruk, dan perilaku malas-malasan merupakan perilaku yang sangat kontras dengan ajaran Islam. Islam sangat menganjurkan kerja keras dan beragama secara kaffah. Terlihat adanya kesulitan bagi orang Bugis berpaling dari kebiasaan lama meskipun ajaran baru (Islam) yang lebih progresif hadir di tengah mereka. Keteguhan mempertahankan adat tidak hanya didasarkan pada keyakinan terhadap adat tersebut, tetapi juga didasarkan pada jaminan kohesi sosial dalam komunitas.[]

\section{Daftar Pustaka}

Abdullah, Irwan. 1999. “Dari Bounded System ke Borderless Society: Krisis Metode Antropologi dalam Memahami Masyarakat." Jurnal Antropologi Indonesia 23. 
Arsyad, Azhar. 2000. Ke-DDI-an: Sejarah dan Pandangan Atas Isu-isu Kontemporer. Makassar: LKPMB PB DDI.

Damami, Muhammad. 2002. Makna Agama dalam Masyarakat Jawa. Yogyakarta: LESFI.

Durkheim, Emile. 1995. The Elementary Forms of Religious Life. New York: The Free Press.

Geertz, Clifford. 1983. Abangan, Santri, Priyayi dalam MasyarakatJawa. terj. A. Mahasin, B. Rasuanto, P. Suparlan, dan H. W. Bachtiar. Jakarta: Pustaka Jaya.

Geertz, Clifford. 1973. The Interpretation of Cultures. New York: Basic.

Hamzah, P., ed. 1984. Monografi Kebudayaan Bugis di Sulawesi Selatan. Ujung Pandang: Pemda Tk. I Sulawesi Selatan.

Hasse, J. 2008. “Agama Tolotang di Tengah Dinamika Sosio-Politik Indonesia: Konstruksi Negara Atas Komunitas Tolotang di Sulawesi Selatan." dalam Agama dan Kearifan Lokal dalam Tantangan Global, ed. I. Abdullah. Yogyakarta: Sekolah Pascasarjana UGM - Pustaka Pelajar.

Hasse, J. 2018. Kontestasi Identitas Agama: Lokalitas Spiritual di Indonesia. Yogyakarta: The Phinisi Press - Program Studi Politik Islam UMY.

Kambie, A. S. 2003. Akar Kenabian Sawerigading: Tapak Tilas Jejak Ketuhanan Yang Maha Esa dalam Kitab I Lagaligo (Sebuah Kajian Hermeneutik). Makassar: Parasufia.

Karim, M. Abdul. 2007. Islam Nusantara. Yogyakarta: Pustaka Book Publisher.

Kesuma, Andi Ima. 2004. Migrasi dan Orang Bugis. Yogyakarta: Ombak.
Makin, Al. 2016. Keberagaman dan Perbedaan: Budaya dan Agama dalam Lintas Sejarah Manusia. Yogyakarta: SUKA Press.

Nasruddin, Nasruddin. 2017. "Tradisi Mappamula (Panen Pertama) pada Masyarakat Bugis Tolotang di Sidenreng Rappang (Kajian Antropologi Budaya)." Rihlah Jurnal Sejarah dan Kebudayaan 5(1):115. Retrieved (http://journal.uinalauddin.ac.id/index.php/rihlah/article/ view/3179).

Pelras, Christian. 2006. Manusia Bugis. Jakarta: Nalar-Forum Jakarta-Paris.

Rustan, Ahmad Sultra. 2018. Pola Komunikasi Orang Bugis: Kompromi Antara Islam dan Adat. Yogyakarta: Pustaka PelajarIAIN Parepare.

Said, Abdul Aziz. 2004. Toraja: Simbolisme Unsur Visual Rumah Tradisional. Yogyakarta: Ombak.

Sewang, Ahmad. 2005. Islamisasi Kerajaan Gowa Abad XVI Sampai Abad XVII. Jakarta: Yayasan Obor Indonesia.

Sumbulah, Ummi. 2012. "Islam Jawa dan Akulturasi Budaya: Karakteristik, Variasi dan Ketaatan Ekspresif." El-Harakah 14(1):51-68. Retrieved (http://ejournal. uin-malang.ac.id/index.php/infopub/ article/view/2191).

Suryadinata, L. 2003. Indonesia's Population: Ethnicity and Religion in a Changing Political Landscape. Singapore: ISEAS Publishing.

Tohopi, Ridwan. 2012. “Tradisi Peraraan Isra' Mi'raj dalam Budaya Islam Lokal Masyarakat Gorontalo." El-Harakah 14(1): 135-55. Retrieved (http://ejournal.uinmalang.ac.id/index.php/infopub/ article/view/2192). 